\title{
Stem Cell Therapy in Diabetes Mellitus
}

\author{
Poondy Gopalratnam Raman* \\ MGM Medical College, 72, Dhar Kothi, Indore, India \\ Received: 制 November 20, 2018; Published: 制 November 27, 2018 \\ *Corresponding author: Poondy Gopalratnam Raman, MGM Medical College, 72, Dhar Kothi, Indore, India
}

\section{Mini Review}

Diabetes Mellitus is a chronic disorder characterized by hyperglycemia due to insulin deficiency or insulin resistance. There is no permanent cure for Diabetes. Only way is to replace insulin producing beta-cells. Whole pancreatic transplantation and purified pancreatic islets transplantation are the answer to cure for diabetes. But scarcity of suitable donor and morbidity, high cost involved are limiting factors for pancreatic transplantation. Islet cell transplantation is less invasive procedure and safer than total pancreatic transplantation established in year 2000. Isolated islets carry less antigenic property, need less immunosuppression with fewer side effects. But major disadvantage is the life-long commitment of immune suppression which is costly and has side effects. High dose calcineurin inhibitor therapy worsens nephropathy [1]. After the islet transplantation, the clinical improvement in hyperglycemia lasts for 2 years. Subsequently, the islet function declines. Unless more cells are transplanted, euglycemia is not maintained. Patients eventually returns to full insulin dependency [2,3].

Stem cells hold great promise to provide a ready source of transplantable, insulin secreting tissues. Soria et al. [4] showed that isolated beta-cells in the absence of other islet cells are less responsive to changes in glucose concentration than intact islet clusters made up of all islet cell types. Hence, stem or precursor cell types can be cultured to produce all cells of islet clusters. The main goal is not only insulin bio-synthesis but also its correct processing, storage and regulator secretion in response to physiological signals. Soft permeable coating has been developed to hide cells from the immune system. This protect cell from an immune attack while allowing them to sense glucose and secrete insulin in response to hyperglycemia. Even if cells do not survive for a patient's lifetime, bio-degradable coatings will break down in the body, could theoretically allow new cells to be transplanted without recovering the build-up or removal of capsule skeleton. The most extensive human trials were conducted in Moscow. The Auckland, New Zealand company uses beads made up of alginate - a gel forming polymer. They reported a trial involving 7 type-1 DM patients who received transplants of alginate encapsulated, neonatal pig islet cells. Present encapsulated strategies have yet to show efficient performance of islets. Encapsulated stem cells derived therapies in diabetes may ultimately work.

Potential Sources of Beta-Cells Therapy in Diabetes [1]

a. Xenogenic islet cells

b. Human islet cells from cadaver

c. Engineered insulin producing cells

d. Stem cells - embryonic stem cells

e. Adult stem cells from bone-marrow and from umbilical cord

f. Pancreatic stem cells from pancreatic duct

Stem cell therapy implies the replacement of diseased or lost cells from progeny of pluripotent or multi-potent cells. Both embryonic stem cells (derived from inner cell mass of a blastocyte) and adult stem cells have been used to generate surrogate beta cells. There is failure in trans-differential into pancreatic beta cells after transplantation of bone-marrow cells in mice. Finding the right way to protect cells and intellectual property will be key for getting cell therapy to patients. Human Embryonic Stem Cells when differentiated into beta cells do not respond correctly to cues in the blood stream i.e. not property responding to glucose level. Transplanting less mature cells into mice showed improvement in diabetes, but tumors developed in $5 \%$ of the treated mice suggesting that some of the pro generator cells never stopped dividing. At the moment encapsulation is the only way to ensure prevention of tumors and autoimmune attack.

In autologous stem cell therapy, the stem cells are given into pancreatic artery via catheter. Patient who cannot safely undergo catheterization procedure may elect to receive the stem cells intravenously. Overall improvement reported in studies included more stable blood glucose, lower fasting blood sugar, decreased leg pain, lower B.P. and absence of hypoglycemia. In 25\%, there was improvement in erectile function. On stem cell therapy, there is 
lot of hope and it seems that we are almost near the goal of curing diabetes. But still, there are many hurdles to overcome. May be in the next decade this will become a primary mode of therapy for Diabetes Mellitus.

\section{References}

1. Mahmood Sanger, Muthuswamy, Balasubramanyam, Viswanathan Mohan (2006) Stem cells on Diabetes. Current Science 91(9).
This work is licensed under Creative Commons Attribution 4.0 License

To Submit Your Article Click Here: Submit Article

DOI: $10.32474 / A D 0.2018 .01 .000123$
2. Flourina P, Shapiro AM, Ricordi C, Secchui A (2008) Clinical impact of islet transplanation, American Journal of Transplant 8(10): 1990-1997.

3. Korsgren O, Lundgren T, Felldin M, Foss A, Isaksson B (2008) Optimising islet engraftment is critical for successful clinical transplantation. Diabetologia 51(2): 227-232.

4. Sorea B, Martin F, Andrew E, Sancheoz Andres J, Nachar V, et al. (1996) Diminished fractions of blockadable ATP sensitive $\mathrm{K}+$ channels in islets transplanted into diabetic mice, Diabetes pp. 1755-1760.

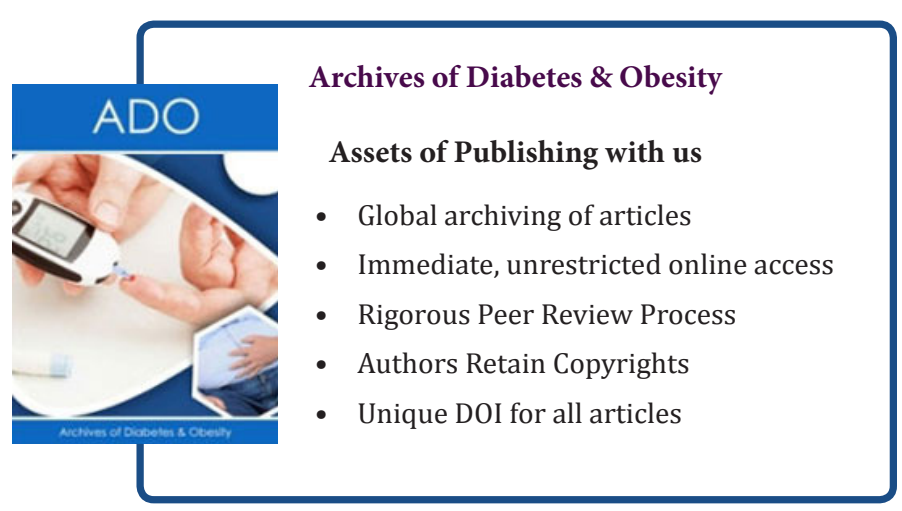

